\title{
Review
}

\section{The Emerging Role of Combination Angiogenesis Inhibitors and Immune Checkpoint Inhibitors in the Treatment of Metastatic Renal Cell Cancer}

\author{
Amanda Nizam ${ }^{\mathrm{a}}$, Logan P. Rhea ${ }^{\mathrm{b}}$, Brinda Gupta ${ }^{\mathrm{c}}$ and Jeanny B. Aragon-Ching ${ }^{\mathrm{d}, *}$ \\ ${ }^{a}$ Department of Medicine, The George Washington University School of Medicine and Health Sciences, \\ Washington, DC, USA \\ ${ }^{\mathrm{b}}$ Department of Medicine, Inova Fairfax Hospital, Fairfax, VA, USA \\ ${ }^{\mathrm{c} V i r g i n i a}$ Commonwealth University School of Medicine, Richmond, VA, USA \\ ${ }^{\mathrm{d}}$ Genitourinary Oncology, Inova Schar Cancer Institute, Fairfax, VA, USA
}

Received 15 December 2018

Accepted 28 February 2019

\begin{abstract}
The advent of vascular endothelial growth factor (VEGF) tyrosine kinase inhibitors (TKIs) a decade ago revolutionized the treatment paradigm in advanced metastatic clear cell renal cell carcinoma (RCC) with improved survival rates compared to the pre-TKI era. Monotherapy with VEGF TKIs has remained first-line. However, sequencing of different TKIs, mammalian target of rapamycin (mTOR) inhibitors, or immune checkpoint inhibitors (ICIs) has been the subject of controversy in the treatment landscape of metastatic RCC. First-line treatment further evolved with the approval of nivolumab plus ipilimumab in intermediate- and poor-risk patients based on an overall survival (OS) benefit demonstrated in the CheckMate214 trial as well as a progression-free survival (PFS) benefit of cabozantinib in the CABOSUN trial. Optimal sequencing, patient selection, and understanding resistance pathways continue to be prominent concerns. Efforts to bypass resistance mechanisms have led to the study of combination therapies. Given enhancement of immune checkpoint inhibitor (ICI) T-cell mediated effects by VEGF-mediated immunosuppression, the combination of VEGF inhibitors and ICIs in treatment-naïve locally advanced and metastatic RCC has shown promise. Available results of phase III trials utilizing these combinations are discussed herein.
\end{abstract}

Keywords: Immunotherapy, VEGF inhibitors, immune checkpoint inhibitors (ICIs), advanced renal cell cancer

\section{INTRODUCTION}

Renal cell carcinoma (RCC) accounts for 65,000 new cases and almost 15,000 deaths each year in the

${ }^{*}$ Correspondence to: Jeanny B. Aragon-Ching, M.D., F.A.C.P., Clinical Program Director of Genitourinary Cancers, INOVA Schar Cancer Institute, Associate Professor of Medicine, Virginia Commonwealth University School of Medicine, 8505 Arlington Blvd., Suite 100, Fairfax, VA, USA. Tel.: +1 703970 6431; Fax: +1 703970 6429; E-mail: Jeanny.Aragon-Ching@inova.org.
United States [1]. While surgery is the cornerstone of treatment for localized or locally advanced kidney cancers, unresectable and metastatic RCC are usually treated with systemic therapy. However, ongoing controversy exists regarding upfront use of cytoreductive nephrectomy given the lack of survival benefit as shown in the CARMENA trial, especially in those with intermediate- or poor-risk disease [2]. The treatment landscape has evolved over the past several years since the initial use of angiogenesis inhibitors. 
Vascular endothelial growth factor (VEGF) tyrosine kinase inhibitors (TKIs) have been used in predominantly favorable-risk patients, while the mammalian target of rapamycin (mTOR) inhibitor temsirolimus has been used in predominantly poor-risk patients [3].

Risk models incorporating different prognostic factors have played a critical role in stratifying patients not only for disease prognostication but also in treatment assignment. The Memorial Sloan Kettering Cancer Center (MSKCC) prognostic model utilizes five factors: two clinical factors including performance status and time from diagnosis to treatment of less than a year and three laboratory parameters including high lactic dehydrogenase (LDH), serum calcium level, and a low hemoglobin, to help stratify patients into favorable (those with 0 risk factors), intermediate (1 or 2 risk factors), or poor-risk (3 or more risk factors) categories. With the MSKCC model, the corresponding overall survival (OS) was incrementally worse for those with poor-risk compared to favorable or intermediate-risk disease (5 months for poor-risk compared to 30 months for favorable vs. 14 months for intermediate; $P<0.001$ ) [4]. Another more contemporary risk model in the era of VEGF-targeted agent use, called the International Metastatic Renal Cell Carcinoma Database Consortium (IMDC), utilizes the same prognostic factors, but with the addition of two laboratory parameters including high platelets and absolute neutrophil counts (ANC) in lieu of the LDH. The IMDC model also stratified patients into favorable, intermediate, or poor-risk. As in the MSKCC model, the IMDC model correlated with worse survival rates for the poor-risk group (8 months) vs. the favorable and intermediaterisk groups (43 months and 22 months, respectively) [5]. These use of these risk models in contemporary trials remains critical in the endeavor to further refine and personalize treatments.

The use of interferon and interleukin has almost historical significance given the potential durability of response, although they were generally considered more toxic therapies [6]. This has led to a great interest in using immunotherapies and immune checkpoint inhibitors (ICIs) in general for the treatment of advanced or metastatic RCC. Nivolumab, a PD-1 inhibitor, became the first ICI approved as 2nd line therapy for previously treated patients with VEGF TKIs. Further success of these agents has moved the combination of nivolumab and ipilimuab to the frontline setting. While VEGF TKIs such as cabozantinib are still utilized in the firstline setting, resistance develops in those treated with single-agent VEGF inhibitors. Therefore, recent trials have attempted to combine agents in an effort to delay resistance to either agent alone. In the following sections, we further elucidate the current and emerging landscape of treatment in metastatic RCC with a discussion of these combination trials.

\section{BACKGROUND ON SYSTEMIC THERAPY FOR ADVANCED RCC}

\section{VEGF inhibitors in the frontline setting}

Sorafenib was the first VEGF TKI that was approved for advanced RCC in 2005 based on the TARGET trial which showed improvement of median progression-free survival (PFS) in sorafenib of 5.5 months compared to placebo at 2.8 months (HR, 0.44; 95\% confidence interval [CI], 0.35 to $0.55 ; P<0.01)$ [7]. Furthermore, partial response was the best response seen in only $10 \%$ of patients compared to $2 \%$ in those who received placebo. Toxicities observed limited the routine first-line use of sorafenib.

Sunitinib became the mainstay of TKI monotherapy approved as first-line treatment for metastatic RCC in 2007. In a multicenter, randomized, phase 3 trial of sunitinib vs. interferon alfa in 750 patients with untreated metastatic RCC, sunitinib demonstrated longer PFS (11 months vs. 5 months; $P<0.001)$ and a higher response rate $(31 \%$ vs. $6 \% ; P<0.001)$ compared to interferon alfa [8]. Pazopanib is another TKI later approved in 2009 [9] as first-line monotherapy in treatment-naïve and cytokine-pretreated patients with metastatic RCC. Its approval was based on demonstrated improvement in PFS (median PFS 9.2 months vs. 4.2 months; $P<0.001)$ and tumor response rate $(30 \%$ vs. $3 \%$, respectively; $P<0.001)$ compared to placebo. Notably, a more discernible benefit in PFS was observed in the treatment-naive group (11.1 months vs. 2.8 months; $P<0.001)$ [10].

Bevacizumab, a VEGF antibody, was studied as an adjunct to interferon alfa in comparison to interferon alfa monotherapy in a randomized, phase III trial in treatment-naïve metastatic clear cell RCC patients, and was approved as a combination therapy in 2009 [11]. While the primary endpoint of OS favored bevacizumab plus interferon alfa, it did not meet predefined criteria for significance but did show improved PFS (median PFS 8.5 months vs. 5.2 months; $P<0.001$ ) [12]. 
The COMPARZ trial demonstrated non-inferiority of pazopanib to sunitinib with regard to the primary endpoint of PFS (8.4 months vs. 9.5 months) [13]. A subsequent cross-over, randomized trial (PISCES) revealed a patient preference for pazopanib over sunitinib ( $70 \%$ vs. $22 \%$ vs. $8 \%$ no preference; $P<0.001)$ given better health-related quality of life [14].

Cabozantinib emerged as a unique TKI with inhibition of multiple receptor tyrosine kinases including VEGF, MET, and AXL, which are involved in tumor cell proliferation and immune cell regulation. Cabozantinib is hypothesized to act synergistically with ICIs by promoting a more favorable immune environment in which ICIs are better able to have an effect $[15,16]$. In the phase II CABOSUN trial comparing cabozantinib vs. sunitinib as initial treatment for patients with IMDC-defined intermediateor poor-risk advanced RCC, investigator-assessed PFS favored cabozantinib vs. sunitinib (median 8.6 months vs. 5.3 months; two-sided $P=0.0008$ ), moving cabozantinib to the frontline for treatment of intermediate- or poor-risk untreated advanced RCC [17].

\section{mTOR Inhibitors}

mTOR inhibitors have been studied in both the first and subsequent-line settings. The pivotal trial that led to the approval of temsirolimus in 2007 [18] demonstrated an overall survival benefit of temsirolimus over interferon alfa monotherapy [19] but no benefit with temsirolimus plus interferon alfa in the first-line setting for patients with poor-risk metastatic RCC (10.9 months vs. 7.3 months vs. 8.4 months, respectively). On the basis of this trial, temsirolimus had initially been a preferred first-line treatment in poorrisk untreated advanced RCC, although the treatment landscape has since changed with the advent of data from cabozantinib and the use of ICI in this setting.

Everolimus has been largely relegated to the second-line setting based on the phase III RECORD1 trial demonstrating prolonged PFS with everolimus compared to placebo (4.9 months vs. 1.9 months; $P<0.0001$ ), but with only a $1.8 \%$ overall response rates [20]. The use of everolimus in the secondline setting was further supported by results of the RECORD-3 trial, which compared first-line everolimus followed by second-line sunitinib to the standard order of first-line sunitinib followed by second-line everolimus. Everolimus failed to demonstrate noninferiority to sunitinib as the primary endpoint of PFS noninferiority was not met (21.1 months vs. 25.8 months) [21]. This led to the initial FDA approval of everolimus in the 2nd line setting in 2009.

\section{VEGF inhibitors in the subsequent-line setting}

Given the poor response rates with second-line mTOR inhibitors, several studies have attempted to elucidate the role of VEGF TKIs following progression on standard therapy. Axitinib was the first VEGF TKI to be studied compared to sorafenib in a phase III randomized trial in advanced RCC refractory to prior agents. The primary endpoint of PFS was met, favoring axitinib over sorafenib (6.7 months vs. 4.7 months; $P<0.0001)$. The greatest benefit in PFS was seen in patients previously treated with cytokines (median PFS 12.1 months for axitinib vs. 6.5 months for sorafenib; $P<0.0001$ ), while those refractory to sunitinib were found to have worse PFS (median PFS 4.8 months for axitinib vs. 3.4 months for sorafenib; $P=0 \cdot 0107)$, [22] thus garnering FDA approval for axitinib in 2012.

The phase III METEOR trial comparing cabozantinib with everolimus in the second-line setting established cabozantinib as another standard of care treatment for advanced RCC refractory to firstline VEGF TKIs on the basis of increased OS (21.4 months vs. 17.1 months; $P=0.0002)$, longer PFS (7.4 months vs. 3.9 months; $P<0.0001$ ), and increased objective response rate (ORR) (17\% vs. $3 \% ; P<0.001)$. Notably, cabozantinib is the only TKI to demonstrate benefit in all three endpoints following progression on VEGF TKIs [23, 24]. The trial results led to the initial FDA approval of cabozantinib in the 2nd line post-TKI failure setting [25].

Although VEGF inhibitors and mTOR inhibitors have improved response rates and prolonged PFS, resistance develops in almost all patients treated with these single-agent regimens [3]. Efforts to combine agents to avert resistance led to a randomized, phase II trial evaluating the combination of lenvatinib, a dual VEGFR-fibroblast growth factor receptor (FGFR) inhibitor and a multi-kinase inhibitor (including VEGF, RET and KIT), with the mTOR inhibitor everolimus in the second-line setting. In a 3-arm randomization of lenvatinib plus everolimus, lenvatinib alone, or everolimus alone, lenvatinib plus everolimus resulted in prolonged PFS (14.6 months vs. 5.5 months; $P=0.0005$ ) and median OS (25.5 months vs. 15.4 months; $P=0.024)$ compared to everolimus alone [26]. This led to the FDA approval of the combination in 2016. 


\section{Immune checkpoint Inhibitors}

Nivolumab, a programmed death 1 (PD-1) inhibitor, was approved as second-line treatment of advanced RCC following failure of standard antiangiogenic treatment after demonstrating an OS benefit and fewer grade $3 / 4$ adverse events in comparison to everolimus in the CheckMate 025 trial (25 months vs. 19.6 months; $P<0.002$ ) [27]. The CheckMate 214 trial further expanded on the previous success of nivolumab, comparing the combination of nivolumab and ipilimumab, a cytotoxic T-lymphocyte antigen 4 (CTLA-4) inhibitor, with sunitinib monotherapy in IMDC-defined intermediate- and poor-risk patients with previously untreated advanced RCC [28]. The combination demonstrated a higher 18-month OS rate of $75 \%$ vs. $60 \%$ (median OS not reached in the combination group vs. 26 months), and a higher ORR of $42 \%$ vs. $27 \%$, favoring nivolumab plus ipilimumab over sunitinib monotherapy, effectively moving immunotherapy to the frontline setting for untreated advanced RCC after US FDA approval in April 2018 [29]. However, in an exploratory subgroup analysis of favorable-risk patients, sunitinib maintained a benefit in PFS (15.3 months vs. 25.1 months, $P<0.0001)$ and ORR (29\% vs. 52\%; $P=0.0002)$ compared to the combination regimen, preserving a role for TKIs in favorable-risk groups [30].

\section{EMERGING DATA ON VEGF INHIBITORS AND IMMUNE CHECKPOINT INHIBITORS (ICI)}

The rationale regarding combination of VEGF inhibitors with immune checkpoint inhibitors centers on effects of VEGF-mediated immunosuppression by modifying the tumor microenvironment resulting in a decline in the Treg population as well as myeloidderived suppressor cells [31]. Specifically, VEGF has been found to play a pivotal role in permissive immune suppression of the tumor microenvironment in part by enhancing PD-1 and other T-cell inhibitory checkpoints which theoretically could be reversed by the use of VEGF inhibitors [32]. In addition, tumor hypoxia with resultant recruitment of Treg cells poses an additional mechanism for immune evasion [33]. Thus, reversal of these immunosuppressive effects of VEGF though the use of VEGF inhibitors may further enhance the inherent T-cell mediated effects of the use of ICIs in this setting. Initial early phase combination trials were wrought with potential hepatotoxicity, limiting the development of combination trials such as nivolumab with sunitinib or pazopanib [34] and pembrolizumab with pazopanib [35]. However, later combination trials with more selective agents and optimal dosing showed early safety and efficacy signals, leading to the further advancement into phase III randomized trials (see Table 1) that compared these combinations to the current standard of sunitinib in the first-line metastatic setting.

\section{A. IMMOTION 151: ATEZOLIZUMAB + BEVACIZUMAB VS. SUNITINIB}

The combination of atezolizumab plus bevacizumab was compared to sunitinib in an earlier hypothesis-generating phase II trial, IMmotion 150, which randomized 305 patients to either atezolizumab plus bevacizumab vs. atezolizumab vs. sunitinib [36]. Cross-over was allowed after progression on atezolizumab or sunitinib monotherapy, with the primary endpoint of PFS in both intent-totreat (ITT) analyses and patients with PD-L1+ in $\geq 1 \%$ of immune cells. While anti-tumor activity was observed and median PFS favored the combination of atezolizumab plus bevacizumab (14.7 months vs. 7.8 months), the PFS hazard ratio (HR) of 0.64 for atezolizumab plus bevacizumab vs. sunitinib in PD-L1+ patients was not statistically significant $(P=.095)$. However, mechanistic insights reveal overcoming resistance to immune checkpoint inhibitors is possible through VEGF inhibition [37]. Regardless, the results were encouraging enough to lead to further advancement to the randomized phase III trial, IMmotion 151. In this trial, atezolizumab plus bevacizumab vs. sunitinib were studied in the firstline setting for patients with previously untreated advanced or metastatic clear cell and/or sarcomatoid RCC [38]. The trial enrolled 915 patients with similar baseline characteristics who were stratified by MSKCC prognostic risk criteria, presence of liver metastases, and PD-L1+ expression in tumor tissue $(<1 \%$ or $>1 \%$ of immue cells). Patients were randomized to receive either atezolizumab plus bevacizumab or sunitinib monotherapy. The co-primary endpoints were PFS by investigator assessment in PD-L1+ patients and OS in the ITT population. Key secondary endpoints included PFS in ITT, OS in PD-L1+ patients, ORR, patient-reported outcomes (PROs), as well as safety profile. Of the ITT population, a majority of patients fell within the intermediate MSKCC risk category and $362(40 \%)$ of the patients were PD-L1+. Notably, PD-L1+ patients who received 
Table 1

Ongoing Phase III trials utilizing the combination of VEGF TKIs and Immune Checkpoint Inhibitors (ICIs)

\begin{tabular}{|c|c|c|c|c|c|}
\hline Trial & $\begin{array}{l}\text { Mechanism } \\
\text { of Action }\end{array}$ & Experimental Arms & $\begin{array}{l}\text { Primary } \\
\text { Endpoints }\end{array}$ & Secondary Endpoints & $\begin{array}{l}\text { Associated } \\
\text { Phase I/II trial }\end{array}$ \\
\hline $\begin{array}{l}\text { IMmotion } 151 \\
\text { (NCT02420821) } \\
\text { [38] }\end{array}$ & PD-L1 + TKI & $\begin{array}{l}\text { Atezolizumab } 1200 \mathrm{mg} \text { IV + } \\
\text { bevacizumab } 15 \mathrm{mg} / \mathrm{kg} \text { IV q } \\
3 \text { weeks (6-week cycle) vs. } \\
\text { sunitinib } 50 \mathrm{mg} \text { daily ( } 4 \\
\text { weeks on/2 weeks off) } \\
(n=915)\end{array}$ & $\begin{array}{l}\text { PFS in } \\
\text { PD-L1+; OS } \\
\text { in ITT }\end{array}$ & $\begin{array}{l}\text { OS in PD-L1+; PFS in } \\
\text { ITT; ORR, PROs, } \\
\text { and safety in overall } \\
\text { population }\end{array}$ & $\begin{array}{l}\text { IMmotion } 150 \\
\text { (NCT01984242) } \\
{[36]}\end{array}$ \\
\hline $\begin{array}{l}\text { JAVELIN } 101 \\
\text { (NCT02684006) } \\
\text { [41] }\end{array}$ & PD-L1 + TKI & $\begin{array}{l}\text { Avelumab } 10 \mathrm{mg} / \mathrm{kg} \text { IV q2 } \\
\text { weeks + Axitinib } 5 \mathrm{mg} \text { BID } \\
\text { (6-week cycle) vs. sunitinib } \\
50 \mathrm{mg} \text { daily ( } 4 \text { weeks on/2 } \\
\text { weeks off) }(n=886)\end{array}$ & $\begin{array}{c}\text { PFS, OS in } \\
\text { PD-L1+ }\end{array}$ & $\begin{array}{l}\text { PFS in ITT; ORR, } \\
\text { treatment-related } \\
\text { AEs }\end{array}$ & $\begin{array}{l}\text { JAVELIN } 100 \\
\quad(\text { NCT02493751)[40 }\end{array}$ \\
\hline $\begin{array}{l}\text { KEYNOTE-426 } \\
\text { (NCT02853331) } \\
{[43]}\end{array}$ & PD-1 + TKI & $\begin{array}{l}\text { Pembrolizumab } 200 \mathrm{mg} \text { IV q } 3 \\
\text { weeks + axitinib } 5 \mathrm{mg} \text { BID } \\
\text { (6-week cycle) vs. sunitinib } \\
50 \mathrm{mg} \text { daily ( } 4 \text { weeks on } / 2 \\
\text { weeks off) }(n=840)\end{array}$ & PFS, OS & $\begin{array}{l}\text { ORR, DCR, DOR, } \\
\text { PFS, OS, AEs }\end{array}$ & NCT02133742 [42] \\
\hline $\begin{array}{l}\text { KEYNOTE-581/ } \\
\text { CLEAR } \\
\text { (NCT02811861) } \\
\text { [44] }\end{array}$ & PD-1 + TKI & $\begin{array}{l}\text { Pembrolizumab } 200 \mathrm{mg} \text { IV q } 3 \\
\text { weeks + lenvatinib } \\
20 \mathrm{mg} / \text { day vs. everolimus } \\
5 \mathrm{mg} / \text { day + lenvatinib } \\
18 \mathrm{mg} / \text { day vs. sunitinib } \\
50 \mathrm{mg} \text { daily }(4 \text { weeks on } / 2 \\
\text { weeks off })(n=735)\end{array}$ & PFS & $\begin{array}{l}\text { ORR, OS, HRQOL, } \\
\text { safety }\end{array}$ & NCT02501096 [45] \\
\hline
\end{tabular}

$\mathrm{VEGF}=$ vascular endothelial growth factor; TKI = tyrosine kinase inhibitor; PD-1 = programmed cell death protein 1; PD-L1 - programmed death-ligand $1 ; n=$ number; $\mathrm{q}=$ every; $\mathrm{BID}=$ twice a day; $\mathrm{ORR}=$ objective response rate $\mathrm{OS}=$ Overall survival; $\mathrm{PFS}=$ progression-free survival; ITT = intention-to-treat population; $\mathrm{PRO}=$ patient-reported outcomes; $\mathrm{AE}=$ adverse event; $\mathrm{DCR}=$ disease control rate; $\mathrm{DOR}=$ duration of response; HRQOL = health-related quality of life.

atezolizumab plus bevacizumab had a PFS of 11.2 months (95\% CI: 8.9-15.0) compared to 7.7 months for those who received sunitinib (95\% CI: 6.8-9.7; HR: $0.74 ; P=0.02)$. Similarly, the secondary endpoint of PFS in the ITT population was 11.2 months (95\% CI: 9.6-13.3) in the atezolizumab plus bevacizumab arm compared to 8.4 months in the sunitinib arm (95\% CI: 7.5-9.7; HR: 0.83; $P=0.02)$. For unclear reasons, PFS as assessed by independent review committee improved to a lesser degree for those in the atezolizumab plus bevacizumab arm as compared to the sunitinib arm alone in both the PDL1+ (8.9 months vs 7.2 months, respectively) and ITT (9.6 months vs. 8.3 months, respectively) groups. The ORR for combination therapy was $43 \%$ in the PDL1+ group and $37 \%$ in the ITT group compared to $35 \%$ and $33 \%$, respectively, for those treated with sunitinib alone. Though median OS has yet to be reached, preliminary data favors combination therapy in both the PD-L1+ (HR: 0.67; $P=0.05)$ and ITT (HR: $0.83 ; P=0.09$ ) populations. Importantly, the safety profile and patient reported outcomes also favor atezolizumab plus bevacizumab over sunitinib [39]. Grade 3 or 4 treatment-related adverse events occurred in $40 \%$ of patients in the atezolizumab plus bevacizumab arm compared to $54 \%$ in the sunitinib arm. $16 \%$ of patients treated with the combination required systemic corticosteroids within 30 days. Compared to those treated with sunitinib, patients who received the combination reported milder symptoms with overall better perceived quality of life. Given the significant improvement in PFS and the relatively favorable side-effect profile, the combination atezolizumab plus bevacizumab reflects well within the current treatment framework of mRCC.

\section{B. JAVELIN RENAL 101: AVELUMAB + AXITINIB VS. SUNITINIB}

Early phase $1 \mathrm{~b}$ results from the JAVELIN Renal 100 study showed feasibility of the combination of the PD-L1 inhibitor avelumab with axitinib [40]. This open-label, multicenter dose-finding trial showed objective responses in 6 out of 6 patients $(100 \%, 95 \%$ CI: 54-100) in the initial dose-finding cohort and 26 out of 49 patients $(53 \%, 38-68)$ in the dose-expansion cohort. These results paved the way for the phase III 
trial, Javelin 101, comparing avelumab plus axitinib vs. sunitinib in 886 patients with treatment-naïve, advanced RCC, with updated data recently presented at the European Society of Medical Oncology (ESMO) 2018 conference [41]. Patients were stratified by PD-L1 expression, with 560 patients of the 886 randomized patients in the PD-L1+ group, and randomized in 1:1 fashion to receive either avelumab $10 \mathrm{mg} / \mathrm{kg}$ IV every 2 weeks plus axitinib $5 \mathrm{mg}$ orally twice daily for a 6 -week cycle or sunitinib $50 \mathrm{mg}$ orally daily for 4 weeks on, followed by 2 weeks off. The co-primary endpoints were PFS and OS in patients with PD-L1+ tumor expression. Key secondary endpoints included PFS in the ITT population, ORR, and treatment-related adverse events. Among the PD-L1+ group, patients who received combination therapy had a median PFS of 13.8 months vs. 7.2 months in those who received sunitinib, corresponding to a $39 \%$ reduction in disease progression or death in the avelumab plus axitinib arm compared to the sunitinib arm (HR: 0.61, $P=.001$ ). Notably, median PFS in the overall population was similar to that of the PD-L1+ group with a PFS of 13.8 months in the avelumab plus axitinib arm compared to 8.4 months in the sunitinib arm (HR: 0.61, $P=0.001)$. ORR improved significantly irrespective of PD-L1 status in the overall population. Similar rates of treatmentrelated adverse events occurred among both treatment arms. Median duration of response and OS have yet to be reached, however current data favors treatment with the combination.

\section{KEYNOTE-426: PEMBROLIZUMAB + AXITINIB VS. SUNITINIB}

Axitinib was combined with the anti-PD-1 antibody, pembrolizumab, in an initial dose-finding phase Ib trial that enrolled 52 patients with treatmentnaïve, metastatic clear cell renal cell carcinoma and good performance status [42]. In the dose-finding phase, the primary endpoint was maximum tolerated dose (MTD) as determined by dose-limiting toxicity (DLT) in the first 2 cycles (6 weeks). 3 of the 11 patients had DLTs, rendering a MTD of axitinib $5 \mathrm{mg}$ twice daily and pembrolizumab $2 \mathrm{mg} / \mathrm{kg}$ every 3 weeks.

This was followed by a dose-expansion phase., in which an additional 41 patients were enrolled, with a vast majority of patients meeting IMDC criteria of favorable or intermediate-risk disease. The side effect profile was favorable, with hypertension as the most common adverse event $(23.1 \%)$, and lower rates of fatigue (13.4\%) and hepatotoxicity (11.5\%) compared to previous trials utilizing VEGF inhibitors and PD-1 inhibitors. Best overall response was a complete response in 4 patients $(7.7 \%)$, partial response in $34(65.4 \%)$, and stable disease in 8 patients (15.4\%). The median PFS was 20.9 months $(95 \% \mathrm{CI})$, but median OS was not reached at a minimum follow-up of 17.6 months. The encouraging findings from this early-phase study led to an openlabel phase III multicenter study, KEYNOTE-426, comparing the combination of pembrolizumab plus axitinib to sunitinib in patients with advanced or metastatic renal cell carcinoma (mRCC). Accrual has completed in 840 patients randomly assigned in a $1: 1$ fashion to receive pembrolizumab $200 \mathrm{mg}$ every 3 weeks plus axitinib $5 \mathrm{mg}$ twice daily or sunitinib $50 \mathrm{mg}$ once daily for 4 weeks, followed by 2 weeks off. Based on the first interim analysis by the independent Data Monitoring Committee, the combination of pembrolizumab plus axitinib resulted in statistically significant improvements in OS and PFS compared to sunitinib monotherapy [43]. Full results are anticipated to be reported at the 2019 ASCO Genitourinary Cancers Symposium.

\section{KEYNOTE-581/CLEAR: LENVATINIB + EVEROLIMUS VS. PEMBROLIZUMAB + LENVATINIB VS. SUNITINIB}

KEYNOTE-581/CLEAR is a multicenter, openlabel, phase III study evaluating the efficacy and safety of lenvatinib in combination with everolimus, compared to the combination of pembrolizumab plus lenvatinib, and sunitinib monotherapy as first-line treatment for advanced renal cell carcinoma [44]. An early phase 1b/II trial of lenvatinib plus pembrolizumab in patients with solid tumors showed impressive efficacy data with an ORR of $66.7 \%$ (95\% CI, 47.2-82.7) and a median PFS of 17.7 months (95\% CI, 9.6-NE), [45] leading to the current phase III trial of KEYNOTE-581/CLEAR. Enrolled patients (target enrollment of 735 patients) were randomized 1:1:1 to three arms including lenvatinib $18 \mathrm{mg} /$ day plus everolimus $5 \mathrm{mg} /$ day, lenvatinib $20 \mathrm{mg}$ /day plus pembrolizumab $200 \mathrm{mg}$ every three weeks, or sunitinib $50 \mathrm{mg}$ /day in a 4-week on, 2-week off cycle. The primary endpoint of the trial is PFS lenvatinib plus everolimus or lenvatinib plus pembrolizumab over single-agent sunitinib, as first-line treatment for advanced RCC in improving PFS. Sec- 
ondary endpoints include the ORR, OS, health related quality of life, and safety profiles. Further exploratory endpoints compare duration of response, disease control rate, and clinical benefit rate between groups, as well as analysis of the relationship between blood biomarkers and outcome. There is no planned interim analysis.

\section{E. TIVOZANIB + NIVOLUMAB}

Tivozanib is a highly specific VEGF TKI known to have a lower incidence of class effect adverse events. In a phase II cross-over trial with sorafenib, tivozanib demonstrated potent anti-tumor activity with acceptable safety profiles [46]. Given its high specificity and favorable safety profile, it has been explored as a possible combination treatment with immune checkpoint inhibition. In a phase Ib/II study, tivozanib is studied in combination with the ICI, nivolumab [47].

In the now-complete phase $\mathrm{Ib}$ portion, two dose levels of tivozanib, $1.0 \mathrm{mg}$ and $1.5 \mathrm{mg}$, once daily for 21 days were studied in combination with nivolumab $240 \mathrm{mg}$ every 14 days in a 28 -day cycle. In the phase Ib trials, 18 patients were enrolled and none experienced a DLT. Patients progressing to phase II received $1.5 \mathrm{mg}$ of tivozanib. While all of the enrolled patients experienced some adverse effect, a majority were limited to grades $1-2$. Of the 5 patients (38\%) who experienced grade 3-4 adverse events, one had significant malignant hypertension that was complicated by seizure. Other grade 3-4 adverse events included pneumonitis, stomatitis, and elevated ALT. Hypertension, asthenia and mucositis of all grades each occurred in $31 \%$ of patients. As hypothesized, the combination of highly specific tivozanib with nivolumab appears to be a safe approach to combination therapy with both drugs administered at a full dose, although current data is limited and should be interpreted with caution. As the study enrolls additional patients for the phase II portion, additional data will allow for analysis of efficacy.

\section{DISCUSSION}

The treatment landscape for advanced renal cell carcinoma has evolved considerably since the introduction of TKIs. However, the role of TKI monotherapy and immunotherapy has shifted based on the approval of nivolumab and ipilimumab as well as cabozantinib in the frontline settings. While the combination of nivolumab and ipilimumab comprises current first-line treatment in intermediateand poor-risk patients, there remains a role for TKI monotherapy in favorable-risk populations, as demonstrated in the subgroup analyses of the CheckMate214 trial [30]. Furthermore, cabozantinib has emerged as a new frontline TKI after being studied in a similar population as the CheckMate 214 trial. Although it has garnered the same FDA approval as nivolumab plus ipilimumab, it is theoretically not limited to only intermediate- or poor-risk patients based on its unique mechanism involving VEGF, MET, and AXL inhibition. TKI monotherapy may move to the second-line setting based on retrospective data showing a benefit in those with progressive disease following initial therapy with ICIs [48]. This is particularly relevant given the implications of sequencing regimens if patients fail first-line therapies with immunotherapy and TKI combinations.

Building upon the success of previous regimens that took advantage of complementary mechanisms of action, such as CTLA-4 inhibition and PD-1 inhibition, there is a strong rationale for combining VEGF inhibitors and immunotherapy based on the enhancement of ICI T-cell mediated effects of VEGFmediated immunosuppression. Based on the trials discussed above, VEGF inhibition plus immunotherapy increases response rate, tumor shrinkage rates, and PFS compared to immunotherapy combinations alone, with suggestions that this may extend to OS benefits as well. The addition of VEGF inhibitors also extends benefit to favorable-risk patients compared to intermediate- and poor-risk patients with immunotherapy combinations alone. With improvement in PFS and OS, complete response (CR) may become a new benchmark for determining efficacy of these regimens. To this end, combinations utilizing VEGF inhibitors with PD-1 inhibitors and CTLA4 inhibitors are underway and appear to be feasible [49].

With evolving treatment combinations, potential toxicities of combination therapy must be considered carefully. Previous combination trials with VEGF inhibitors and immune checkpoint inhibitors have revealed high toxicity levels, leading to an increased effort to find at least additive antitumor activity in treatment-naive patients with advanced renal cell carcinoma. In CheckMate016, the combinations of sunitinib compared to pazopanib with nivolumab showed unacceptable toxicity levels precluding further study of these combination regimens. However, the potentially increased toxicities seen with these 
Table 2

Select early-phase trials utilizing the combination of VEGF TKIs and Immune Checkpoint Inhibitors (ICIs)

\begin{tabular}{|c|c|c|c|c|c|c|}
\hline Trial & Phase & $\begin{array}{l}\text { Mechanism of } \\
\text { Action }\end{array}$ & Experimental Arms & $\begin{array}{l}\text { Primary } \\
\text { Endpoints }\end{array}$ & Secondary Endpoints & $\begin{array}{l}\text { Associated Phase } \\
\text { III trial }\end{array}$ \\
\hline NCT03136627 [47] & $\mathrm{Ib} / \mathrm{II}$ & PD-1 + TKI & $\begin{array}{l}\text { Tivozanib } 1.5 \mathrm{mg} \text { daily x } 21 \\
\quad \text { days (of a } 28 \text {-day cycle) } \\
\quad+\text { nivolumab } 240 \mathrm{mg} \text { IV q } \\
14 \text { days }(n=28)\end{array}$ & MTD/DLT & $\begin{array}{l}\text { Disease status q3 } \\
\text { months in months } \\
1-12 \text {, then q6 months }\end{array}$ & N/A \\
\hline NCT02496208 [49] & $\mathrm{Ib}$ & $\begin{array}{l}\text { PD- } 1+ \\
\quad \text { TKI } \pm \text { CTLA- } 4\end{array}$ & $\begin{array}{l}\text { Nivolumab } 3 \mathrm{mg} / \mathrm{kg} \mathrm{q} 14 \\
\text { days + cabozantinib } \\
40 \mathrm{mg} \text { daily } \\
(n=49) \pm \text { ipilimumab } \\
1 \mathrm{mg} / \mathrm{kg} \mathrm{q} 21 \text { days } \times 4 \\
\text { doses }(n=29)\end{array}$ & MTD/DLT; ORR & PFS & $\begin{array}{l}\text { CHECKMATE 9ER } \\
\text { (NCT03141177)[50] }\end{array}$ \\
\hline $\begin{array}{l}\text { COSMIC-021 } \\
\text { (NCT03170960) [16] }\end{array}$ & $\mathrm{Ib}$ & PD-L1 + TKI & $\begin{array}{l}\text { Cabozantinib } 40 \mathrm{mg} \text { daily }+ \\
\text { atezolizumab } 1200 \mathrm{mg} \mathrm{q} 3 \\
\text { wk }(n=12)\end{array}$ & $\begin{array}{l}\text { Dose Escalation: } \\
\text { MTD/RD Dose } \\
\text { Expansion: ORR }\end{array}$ & AEs and SAEs & N/A \\
\hline
\end{tabular}

$\mathrm{VEGF}=$ vascular endothelial growth factor; TKI = tyrosine kinase inhibitor; CTLA-4 = cytotoxic T-lymphocyte associated protein 4 antibody; $n=$ number; $\mathrm{q}=$ every; $\mathrm{MTD}=$ maximum tolerated dose; $\mathrm{DLT}=$ dose-limiting toxicity; $\mathrm{RD}=$ recommended dose; $\mathrm{AE}=\mathrm{adverse}$ event; $\mathrm{SAE}=$ serious adverse event; $\mathrm{ORR}=$ objective response rate; $\mathrm{OS}=$ Overall survival; $\mathrm{PFS}=$ progression-free survival; $\mathrm{PD}-1=$ programmed cell death protein 1; PD-L1 - programmed death-ligand 1.

combination regimens will need to be weighed against the benefit gained in PFS and CR.

Finally, it is important to note that the majority of patients studied in established trials had a clear-cell histology with favorable- or intermediate-risk disease. Therefore, it is difficult to ascertain how these regimens compare in the setting of different histologic classifications and risk categories of disease, and this is a potential future area of research.

\section{FUTURE DIRECTIONS}

The next wave of standard of care treatment will likely come in the form of trials that utilize the combination of ICIs with VEGF TKIs (see Table 2). Given the rapidly evolving field, current trials that utilize sunitinib alone as the control arm may soon no longer be suitable. On the other hand, questions remain regarding sequencing since these treatments are not expected to work indefinitely. Further understanding of different molecular signatures and biomarker expression in tailoring treatment may be helpful in stratifying patients to different modalities of treatment. Furthermore, combination therapies capitalize on the ability of VEGF TKIs in affecting tumors with high expression of a myeloid inflammatory signature compared to low myeloid suppression since these myeloid-derived suppressor cells are considered barriers to effective cancer immunotherapy effect. In addition, certain VEGF TKIs such as cabozantinib can mediate rapid remodeling of myeloid cells from an immunosuppressive to an antitumor phenotype with priming of circulating cytotoxic $\mathrm{NK}$ and $\mathrm{T}$ cells [15]. Cabozantinib is increasingly being combined with other ICIs $[16,49,50]$. There are certainly implications of sequencing different agents after immune checkpoint inhibitor drugs have been exhausted. While there are insufficient data to suggest optimal outcomes with VEGF TKI treatment post-ICI therapy failure, small retrospective datasets suggest some response can still be seen [48, 51]. Further investigation into combination treatments and use of novel drugs with non-overlapping mechanisms of action would be of paramount importance.

\section{CONCLUSIONS}

The treatment landscape for advanced and metastatic RCC is rapidly evolving. While the ICI combination of nivolumab and ipilimumab has changed the first-line treatment of metastatic RCC with intermediate- and poor-risk disease, the additional option of adding VEGF TKIs to immunotherapy serves as the next wave of revolutionary change in the landscape of treatment for advanced RCC given encouraging results. Established prognostic risk models, analysis of gene expression signatures, and further refinement of prognostic biomarkers will serve to further inform decisions on optimal treatment regimens for patients in the future.

\section{ACKNOWLEDGMENTS}

The authors have no acknowledgments.

\section{FUNDING}

The authors report no funding. 


\section{CONFLICT OF INTEREST}

AN, LR, BG have no conflicts to declare. JBAC serves on the Speakers' Bureau of Bristol Myers Squibb.

\section{REFERENCES}

[1] Siegel RL, Miller KD, Jemal A. Cancer statistics, 2019. CA Cancer J Clin 2019;69:7-34.

[2] Mejean A, Ravaud A, Thezenas S, Colas S, Beauval JB, Bensalah K, Geoffrois L, Thiery-Vuillemin A, Cormier L, Lang H, Guy L, Gravis G, Rolland F, Linassier C, Lechevallier E, Beisland C, Aitchison M, Oudard S, Patard JJ, Theodore C, Chevreau C, Laguerre B, Hubert J, Gross-Goupil M, Bernhard JC, Albiges L, Timsit MO, Lebret T, Escudier B. Sunitinib alone or after nephrectomy in metastatic renal-cell carcinoma. $\mathrm{N}$ Engl $\mathrm{J}$ Med 2018;379:417-27.

[3] Choueiri TK, Motzer RJ. Systemic therapy for metastatic renal-cell carcinoma. N Engl J Med 2017;376:354-66.

[4] Motzer RJ, Bacik J, Murphy BA, Russo P, Mazumdar M. Interferon-alfa as a comparative treatment for clinical trials of new therapies against advanced renal cell carcinoma. J Clin Oncol 2002;20:289-96.

[5] Heng DY, Xie W, Regan MM, Warren MA, Golshayan AR, Sahi C, Eigl BJ, Ruether JD, Cheng T, North S, Venner P, Knox JJ, Chi KN, Kollmannsberger C, McDermott DF, Oh WK, Atkins MB, Bukowski RM, Rini BI, Choueiri TK. Prognostic factors for overall survival in patients with metastatic renal cell carcinoma treated with vascular endothelial growth factor-targeted agents: Results from a large, multicenter study. J Clin Oncol 2009;27:57949.

[6] Klapper JA, Downey SG, Smith FO, Yang JC, Hughes MS, Kammula US, Sherry RM, Royal RE, Steinberg SM, Rosenberg S. High-dose interleukin-2 for the treatment of metastatic renal cell carcinoma: A retrospective analysis of response and survival in patients treated in the surgery branch at the National Cancer Institute between 1986 and 2006. Cancer 2008;113:293-301.

[7] Escudier B, Eisen T, Stadler WM, Szczylik C, Oudard S, Siebels M, Negrier S, Chevreau C, Solska E, Desai AA, Rolland F, Demkow T, Hutson TE, Gore M, Freeman S, Schwartz B, Shan M, Simantov R, Bukowski RM. Sorafenib in advanced clear-cell renal-cell carcinoma. N Engl J Med 2007;356:125-34.

[8] Motzer RJ, Hutson TE, Tomczak P, Michaelson MD, Bukowski RM, Rixe O, Oudard S, Negrier S, Szczylik C, Kim ST, Chen I, Bycott PW, Baum CM, Figlin RA. Sunitinib vs. interferon alfa in metastatic renal-cell carcinoma. N Engl J Med 2007;356:115-24.

[9] Ward JE, Stadler WM. Pazopanib in renal cell carcinoma. Clin Cancer Res 2010;16:5923-7.

[10] Sternberg CN, Davis ID, Mardiak J, Szczylik C, Lee E, Wagstaff J, Barrios CH, Salman P, Gladkov OA, Kavina A, Zarba JJ, Chen M, McCann L, Pandite L, Roychowdhury DF, Hawkins RE. Pazopanib in locally advanced or metastatic renal cell carcinoma: Results of a randomized phase III trial. J Clin Oncol 2010;28:1061-8.

[11] Summers J, Cohen MH, Keegan P, Pazdur R. FDA drug approval summary: Bevacizumab plus interferon for advanced renal cell carcinoma. Oncologist 2010;15:104-11.
[12] Rini BI, Halabi S, Rosenberg JE, Stadler WM, Vaena DA, Archer L, Atkins JN, Picus J, Czaykowski P, Dutcher J, Small EJ. Phase III trial of bevacizumab plus interferon alfa vs. interferon alfa monotherapy in patients with metastatic renal cell carcinoma: Final results of CALGB 90206. J Clin Oncol 2010;28:2137-43.

[13] Motzer RJ, Hutson TE, Cella D, Reeves J, Hawkins R, Guo J, Nathan P, Staehler M, de Souza P, Merchan JR, Boleti E, Fife K, Jin J, Jones R, Uemura H, De Giorgi U, Harmenberg U, Wang J, Sternberg CN, Deen K, McCann L, Hackshaw MD, Crescenzo R, Pandite LN, Choueiri TK. Pazopanib vs. sunitinib in metastatic renal-cell carcinoma. $\mathrm{N}$ Engl J Med 2013;369:722-31.

[14] Escudier B, Porta C, Bono P, Powles T, Eisen T, Sternberg $\mathrm{CN}$, Gschwend JE, De Giorgi U, Parikh O, Hawkins R, Sevin E, Negrier S, Khan S, Diaz J, Redhu S, Mehmud F, Cella D. Randomized, controlled, double-blind, crossover trial assessing treatment preference for pazopanib vs. sunitinib in patients with metastatic renal cell carcinoma: PISCES Study. J Clin Oncol 2014;32:1412-8.

[15] Verzoni E, Ferro S, Procopio G, Cova A, Ratta R, Raimondi A, Pepe S, Squarcina P, Lalli V. Potent Natural Killer (NK) and myeloid blood cell remodeling by Cabozantinib (Cabo) in pretreated metastatic renal cell carcinoma (mRCC) patients. Ann Oncol 2018;29(suppl_8):viii303viii331.

[16] Agarwal N, Vaishampayan U, Green M, di Nucci F, Chang P-Y, Scheffold C, Pal SK. Phase Ib study (COSMIC-021) of cabozantinib in combination with atezolizumab: Results of the dose escalation stage in patients (pts) with treatmentnaïve advanced renal cell carcinoma (RCC). Ann Oncol 2018;9(suppl_8):viii303-viii331.

[17] Choueiri TK, Halabi S, Sanford BL, Hahn O, Michaelson MD, Walsh MK, Feldman DR, Olencki T, Picus J, Small EJ, Dakhil S, George DJ, Morris MJ. Cabozantinib vs. sunitinib as initial targeted therapy for patients with metastatic renal cell carcinoma of poor or intermediate risk: The alliance A031203 CABOSUN trial. J Clin Oncol 2017;35:591-7.

[18] Kwitkowski VE, Prowell TM, Ibrahim A, Farrell AT, Justice R, Mitchell SS, Sridhara R, Pazdur R. FDA approval summary: Temsirolimus as treatment for advanced renal cell carcinoma. Oncologist 2010;15:428-35.

[19] Hudes G, Carducci M, Tomczak P, Dutcher J, Figlin R, Kapoor A, Staroslawska E, Sosman J, McDermott D, Bodrogi I, Kovacevic Z, Lesovoy V, Schmidt-Wolf IG, Barbarash O, Gokmen E, O'Toole T, Lustgarten S, Moore L, Motzer RJ. Temsirolimus, interferon alfa, or both for advanced renal-cell carcinoma. N Engl J Med 2007;356:2271-81.

[20] Motzer RJ, Escudier B, Oudard S, Hutson TE, Porta C, Bracarda S, Grunwald V, Thompson JA, Figlin RA, Hollaender N, Kay A, Ravaud A. Phase 3 trial of everolimus for metastatic renal cell carcinoma: Final results and analysis of prognostic factors. Cancer 2010;116:4256-65.

[21] Motzer RJ, Barrios CH, Kim TM, Falcon S, Cosgriff T, Harker WG, Srimuninnimit V, Pittman K, Sabbatini R, Rha SY, Flaig TW, Page R, Bavbek S, Beck JT, Patel P, Cheung FY, Yadav S, Schiff EM, Wang X, Niolat J, Sellami D, Anak O, Knox JJ. Phase II randomized trial comparing sequential first-line everolimus and second-line sunitinib vs. first-line sunitinib and second-line everolimus in patients with metastatic renal cell carcinoma. J Clin Oncol 2014;32:2765-72.

[22] Rini BI, Escudier B, Tomczak P, Kaprin A, Szczylik C, Hutson TE, Michaelson MD, Gorbunova VA, Gore ME, 
Rusakov IG, Negrier S, Ou YC, Castellano D, Lim HY, Uemura H, Tarazi J, Cella D, Chen C, Rosbrook B, Kim S, Motzer RJ. Comparative effectiveness of axitinib vs. sorafenib in advanced renal cell carcinoma (AXIS): A randomised phase 3 trial. Lancet 2011;378:1931-9.

[23] Choueiri TK, Escudier B, Powles T, Mainwaring PN, Rini BI, Donskov F, Hammers H, Hutson TE, Lee JL, Peltola K, Roth BJ, Bjarnason GA, Geczi L, Keam B, Maroto P, Heng DY, Schmidinger M, Kantoff PW, Borgman-Hagey A, Hessel C, Scheffold C, Schwab GM, Tannir NM, Motzer RJ. Cabozantinib vs. everolimus in advanced renal-cell carcinoma. N Engl J Med 2015;373:1814-23.

[24] Choueiri TK, Escudier B, Powles T, Tannir NM, Mainwaring PN, Rini BI, Hammers HJ, Donskov F, Roth BJ, Peltola K, Lee JL, Heng DYC, Schmidinger M, Agarwal N, Sternberg CN, McDermott DF, Aftab DT, Hessel C, Scheffold C, Schwab G, Hutson TE, Pal S, Motzer RJ. Cabozantinib vs. everolimus in advanced renal cell carcinoma (METEOR): Final results from a randomised, open-label, phase 3 trial. Lancet Oncol 2016;17:917-27.

[25] Singh H, Brave M, Beaver JA, Cheng J, Tang S, Zahalka E, Palmby TR, Venugopal R, Song P, Liu Q, Liu C, Yu J, Chen XH, Wang X, Wang Y, Kluetz PG, Daniels SR, Papadopoulos EJ, Sridhara R, McKee AE, Ibrahim A, Kim G, Pazdur R. U.S. food and drug administration approval: Cabozantinib for the treatment of advanced renal cell carcinoma. Clin Cancer Res 2017;23: 330-5.

[26] Motzer RJ, Hutson TE, Glen H, Michaelson MD, Molina A, Eisen T, Jassem J, Zolnierek J, Maroto JP, Mellado B, Melichar B, Tomasek J, Kremer A, Kim HJ, Wood K, Dutcus C, Larkin J. Lenvatinib, everolimus, and the combination in patients with metastatic renal cell carcinoma: A randomised, phase 2, open-label, multicentre trial. Lancet Oncol 2015; 16:1473-82.

[27] Motzer RJ, Escudier B, McDermott DF, George S, Hammers HJ, Srinivas S, Tykodi SS, Sosman JA, Procopio G, Plimack ER, Castellano D, Choueiri TK, Gurney H, Donskov F, Bono P, Wagstaff J, Gauler TC, Ueda T, Tomita Y, Schutz FA, Kollmannsberger C, Larkin J, Ravaud A, Simon JS, Xu LA, Waxman IM, Sharma P. Nivolumab vs. everolimus in advanced renal-cell carcinoma. N Engl J Med 2015;373:1803-13

[28] Motzer RJ, Tannir NM, McDermott DF, Aren Frontera O, Melichar B, Choueiri TK, Plimack ER, Barthelemy P, Porta C, George S, Powles T, Donskov F, Neiman V, Kollmannsberger CK, Salman P, Gurney H, Hawkins R, Ravaud A, Grimm MO, Bracarda S, Barrios CH, Tomita Y, Castellano D, Rini BI, Chen AC, Mekan S, McHenry MB, Wind-Rotolo M, Doan J, Sharma P, Hammers HJ, Escudier B. Nivolumab plus ipilimumab vs. sunitinib in advanced renal-cell carcinoma. N Engl J Med 2018;378:1277-90.

[29] Nizam A, Aragon-Ching JB. Frontline immunotherapy treatment with nivolumab and ipilimumab in metastatic renal cell cancer: A new standard of care. Cancer Biol Ther 2018;1-2.

[30] Escudier B, Tannir NM, McDermott DF, Frontera OA, Melichar B, Plimack ER, Barthelemy P, George S, Neiman V, Porta C, Choueiri TK, Powles T, Donskov F, Salman P, Kollmannsberger CK, Rini B, Mekan S, McHenry MB, Hammers HJ, Motzer RJ. LBA5: CheckMate 214: Efficacy and safety of nivolumab + ipilimumab (N+I) v sunitinib (S) for treatment-naïve advanced or metastatic renal cell carcinoma (mRCC), including IMDC risk and PD-L1 expression subgroups. Annals of Oncology 2017;28:mdx440.029mdx440.029.

[31] Gabrilovich DI, Nagaraj S. Myeloid-derived suppressor cells as regulators of the immune system. Nat Rev Immunol 2009;9:162-74.

[32] Voron T, Colussi O, Marcheteau E, Pernot S, Nizard M, Pointet AL, Latreche S, Bergaya S, Benhamouda N, Tanchot C, Stockmann C, Combe P, Berger A, Zinzindohoue F, Yagita H, Tartour E, Taieb J, Terme M. VEGF-A modulates expression of inhibitory checkpoints on CD8+ T cells in tumors. J Exp Med 2015;212:139-48.

[33] Facciabene A, Peng X, Hagemann IS, Balint K, Barchetti A, Wang LP, Gimotty PA, Gilks CB, Lal P, Zhang L, Coukos G. Tumour hypoxia promotes tolerance and angiogenesis via CCL28 and T(reg) cells. Nature 2011;475:226-30.

[34] Amin A, Plimack ER, Ernstoff MS, Lewis LD, Bauer TM, McDermott DF, Carducci M, Kollmannsberger C, Rini BI, Heng DYC, Knox J, Voss MH, Spratlin J, Berghorn E, Yang L, Hammers HJ. Safety and efficacy of nivolumab in combination with sunitinib or pazopanib in advanced or metastatic renal cell carcinoma: The CheckMate 016 study. J Immunother Cancer 2018;6:109.

[35] Chowdhury S, McDermott DF, Voss MH, Hawkins RE, Aimone P, Voi M, Isabelle N, Wu Y, Infante JR. A phase I/II study to assess the safety and efficacy of pazopanib (PAZ) and pembrolizumab (PEM) in patients (pts) with advanced renal cell carcinoma (aRCC). J Clin Oncol 2017;35:4506.

[36] Atkins MB, McDermott DF, Powles T, Motzer RJ, Rini BI, Fong L, Joseph RW, Pal SK, Sznol M, Hainsworth JD, Stadler WM, Hutson TE, Ravaud A, Bracarda S, Suarez C, Choueiri TK, Qiu J, Huseni MA, Schiff C, Escudier BJ. IMmotion150: A phase II trial in untreated metastatic renal cell carcinoma (mRCC) patients (pts) of atezolizumab (atezo) and bevacizumab (bev) vs and following atezo or sunitinib (sun). Journal of Clinical Oncology 2017;35:4505.

[37] McDermott DF, Huseni MA, Atkins MB, Motzer RJ, Rini BI, Escudier B, Fong L, Joseph RW, Pal SK, Reeves JA, Sznol M, Hainsworth J, Rathmell WK, Stadler WM, Hutson T, Gore ME, Ravaud A, Bracarda S, Suarez C, Danielli R, Gruenwald V, Choueiri TK, Nickles D, Jhunjhunwala S, Piault-Louis E, Thobhani A, Qiu J, Chen DS, Hegde PS, Schiff C, Fine GD, Powles T. Publisher Correction: Clinical activity and molecular correlates of response to atezolizumab alone or in combination with bevacizumab vs. sunitinib in renal cell carcinoma. Nat Med 2018.

[38] Motzer RJ, Powles T, Atkins MB, Escudier B, McDermott DF, Suarez C, Bracarda S, Stadler WM, Donskov F, Lee J-L, Hawkins RE, Ravaud A, Alekseev BY, Staehler MD, Uemura M, Donaldson F, Li S, Huseni MA, Schiff C, Rini BI. IMmotion151: A randomized phase III study of atezolizumab plus bevacizumab vs sunitinib in untreated metastatic renal cell carcinoma (mRCC). J Clin Oncol 2018;36:578.

[39] Escudier B, Motzer RJ, Rini BI, Powles T, McDermott DF, Suarez C, Bracarda S, Stadler WM, Donskov F, Gurney H, Oudard S, Uemura M, Lam ET, Grüllich C, Ding B, Khaznadar T, Quach C, Piault E, Schiff C, Atkins MB. Patient-reported outcomes (PROs) in IMmotion151: Atezolizumab (atezo) + bevacizumab (bev) vs sunitinib (sun) in treatment (tx) naive metastatic renal cell carcinoma (mRCC). J Clin Oncol 2018;36:4511.

[40] Choueiri TK, Larkin J, Oya M, Thistlethwaite F, Martignoni M, Nathan P, Powles T, McDermott D, Robbins PB, Chism DD, Cho D, Atkins MB, Gordon MS, Gupta S, Uemura 
H, Tomita Y, Compagnoni A, Fowst C, di Pietro A, Rini BI. Preliminary results for avelumab plus axitinib as firstline therapy in patients with advanced clear-cell renal-cell carcinoma (JAVELIN Renal 100): An open-label, dosefinding and dose-expansion, phase $1 \mathrm{~b}$ trial. Lancet Oncol 2018;19:451-60.

[41] Motzer RJ, Penkov K, Haanen JBAG, Rini BI, Albiges L, Campbell MT, Kollmannsberger CK, Negrier S, Uemura M, Lee JL, Gurney H, Berger R, Schmidinger M, Larkin $\mathrm{J}$, Atkins MB, Wang J, Robbins PB, Chudnovsky A, Di Pietro A, Choueiri TK. LBA6_PRJAVELIN renal 101: A randomized, phase III study of avelumab + axitinib vs sunitinib as first-line treatment of advanced renal cell carcinoma (aRCC). Annals of Oncology 2018;29:mdy424.036-mdy424.036.

[42] Atkins MB, Plimack ER, Puzanov I, Fishman MN, McDermott DF, Cho DC, Vaishampayan U, George S, Olencki TE, Tarazi JC, Rosbrook B, Fernandez KC, Lechuga M, Choueiri TK. Axitinib in combination with pembrolizumab in patients with advanced renal cell cancer: A nonrandomised, open-label, dose-finding, and dose-expansion phase 1b trial. Lancet Oncol 2018;19:405-15.

[43] Merck Press Release: Merck's KEYTRUDA® (pembrolizumab) in Combination with Pfizer's Inlyta ${ }^{\circledR}$ (axitinib) Significantly Improved Overall Survival (OS) and Progression-free Survival (PFS) as First-Line Therapy for Advanced or Metastatic Renal Cell Carcinoma, 2018.

[44] Motzer RJ, Grünwald V, Hutson TE, Porta C, Powles T, Eto M, Dutcus CE, Baig MA, Dutta L, Li D, Choueiri TK. A phase 3 trial to compare efficacy and safety of lenvatinib in combination with everolimus or pembrolizumab vs. sunitinib alone in first-line treatment of patients with metastatic renal cell carcinoma. J Clin Oncol 2018;36:TPS706-TPS706.

[45] Lee C-H, Makker V, Rasco DW, Taylor MH, Stepan DE, Shumaker RC, Schmidt EV, Guo M, Dutcus CE, Motzer RJ. Lenvatinib + pembrolizumab in patients with renal cell carcinoma: Updated results. Journal of Clinical Oncology 2018;36:4560.

[46] Molina AM, Hutson TE, Nosov D, Tomczak P, Lipatov O, Sternberg CN, Motzer R, Eisen T. Efficacy of tivozanib treatment after sorafenib in patients with advanced renal cell carcinoma: Crossover of a phase 3 study. Eur J Cancer 2018;94:87-94.
[47] Escudier B, Barthelemy P, Ravaud A, Negrier S, Needle $\mathrm{MN}$, Albiges L. Tivozanib combined with nivolumab: Phase $\mathrm{Ib} / \mathrm{II}$ study in metastatic renal cell carcinoma (mRCC). J Clin Oncol 2018;36:618.

[48] Barata PC, Liano AGd, Mendiratta P, Crolley V, Szabados B, Wood LS, Zanick B, Allman KD, Tyler AJ, Martin A, Gilligan TD, Grivas P, Ornstein MC, Garcia JA, Powles T, Rini BI. Clinical outcome of patients (Pts) with metastatic renal cell carcinoma (mRCC) progressing on frontline immuneoncology based combination (IO-COMBO) regimens. J Clin Oncol 2018;36:613.

[49] Nadal RM, Mortazavi A, Stein M, Pal SK, Davarpanah NN, Parnes HL, Ning Y-M, Cordes LM, Bagheri MH, Lindenberg L, Thompson R, Steinberg SM, Moore T, Lancaster T, Velez M, Mena E, Costello R, Bottaro D, Dahut WL, Apolo AB. Results of phase I plus expansion cohorts of cabozantinib (Cabo) plus nivolumab (Nivo) and CaboNivo plus ipilimumab (Ipi) in patients (pts) with with metastatic urothelial carcinoma (mUC) and other genitourinary (GU) malignancies. J Clin Oncol 2018;36:515.

[50] Choueiri TK, Apolo AB, Powles T, Escudier B, Aren OR, Shah A, Kessler ER, Hsieh JJ, Zhang J, Simsek B, Scheffold C, Motzer RJ. A phase 3, randomized, open-label study of nivolumab combined with cabozantinib vs sunitinib in patients with previously untreated advanced or metastatic renal cell carcinoma (RCC; CheckMate 9ER). J Clin Oncol 2018;36:TPS4598-TPS4598.

[51] Shah AY, Lemke E, Gao J, Chandramohan A, Campbell MT, Zurita AJ, Xiao L, Wang J, Corn PG, Jonasch E, Sharma P, Tannir NM. Outcomes of patients (pts) with metastatic clear-cell renal cell carcinoma (mCCRCC) treated with second-line (2L) vascular endothelial growth factor receptor tyrosine kinase inhibitors (VEGFR-TKI) after first-line (1L) immune checkpoint inhibitors (ICI). J Clin Oncol 2018;36:682. 